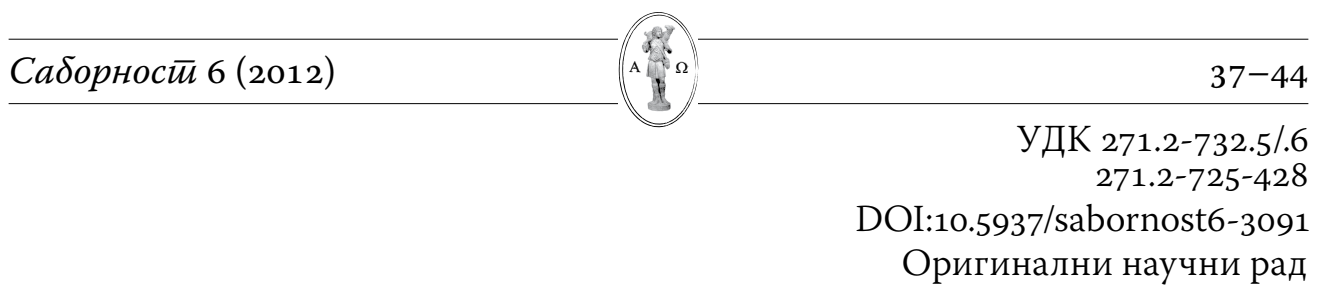

\title{
Зоран Крстић"
}

Универзитет у Београду, Православни богословски факултет, Београд

\section{Клерикализам и лаицизам - две крајњости у разумевању служби у Цркви ${ }^{1}$}

\begin{abstract}
: Аутор у раду анализира претераности у разумевању садржаја црквених служби које су се кроз историју најчешће манифестовале као клерикализам као један пол и лаицизам као његова супротност. Почињући од клерикализма указује се на различите облике које је он задобијао током историје, попут политичког, друштвеног и културалног клерикализма. Акценат у анализи аутор ставља на разматрање клерикализма у црквеној заједници видећи његове почетке и узроке у ткз. теорији о посвећењу која се на различите начине испољавала у црквеном животу Западне и Источне Цркве. Прва последица ове теорије је промена термина лаик у смислу члана народа Божијег у мирјанин у смислу онога који је од света. Друга последица је мања или већа пасивизација лаика у црквеном животу. Разрешење проблема аутор види у реактуализацији предањске еклисиологије која поистовећује службу и дарове Духа Светог те тако не раздваја институционалну од харизматске структуре Цркве. У последњем делу се разматрају последице лаицизмана црквени живот као реакције на претерани клерикализам.
\end{abstract}

Key words: служठа, клерикализам, лаицизам, мирјанин, воља Божија, структура Цркве.

$\mathrm{Y}$ западној теологији се од Реформације до данас, више пута дешавало „откриће“ лаика. Најпре је сама Реформација оштро увела тај проблем у жижу интересовања, а после више векова је нешто слично учинио и Други Ватикански концил, да нагласим само ове две тачке кулминирања поменутог проблема у оквирима западне теологије, иако је он у различитим облицима и различитом интензитету присутан више векова све до данас.

Православна теологија тој теми није придавала толики значај. Међутим, оно што се није десило у теологији, десило се у црквеној пракси, а посебно у области црквене управе. Новија законодавства помесних православних

zorank62@gmail.com

1 Излагање на међународном симпосиону „Црква, лаици, друштво у Бугарској“ одржаном 2. и 3. новембра 2012. године у Софији. 
38 Крстић, 3. Клерикализам и лаицизам - gве крајњостии у разумевању служби у Цркви-

цркава додељују, као својеврсну реакцију и одговор на проблематику западне теологије, прилично места лаицима и тако је „било неминовно да се појави несклад између црквене праксе и богословског учења. Црквена пракса се нашла без богословске заснованости, а богословско учење не одговара црквеној пракси." (Афанасјев, 2001, стр. 5).

Циљ овог рада је да указивањем и анализом претераности у разумевању служби у Цркви, а коју репрезентују појмови клерикализам и лаицизам као два супротна пола, дођемо до уравнотеженог, еклисиолошки оправданог садржаја и смисла појма служби.

\section{1. Клерикализам}

Сам појам клерикализам као и његова супротност антиклерикализам су често у употреби али не увек са истим садржајем, а који опет, није тако лако одредити у свом историјском, друштвеном и теолошком контексту, уз свест о разликама између Истока и Запада такође у историјској, друштвеној и црквеној реалности. Као и сваки „изам“ он означава одређену идеолошку апсолутизацију, најчешће и девијацију, те тако поприма негативну конотацију.

Најопштије говорећи под клерикализмом подразумевамо превласт клира у Цркви и друштву. Противлерикализам је релативно лакше одредити јер он представља суштинску карактеристику првобитног грађанског лиঠерализма и епохе просвећености, и тако је, у неку руку, уграђен у саме темеље модерности. Пошто он, међутим, није предмет наше анализе враћам се клерикализму и његовим појавним облицима.

\section{2. Клерикализам у друштву}

Утицај клира у друштву се у много јаснијим формама и репрезентативније јавља на Западу него на Истоку, тако да на хришћанском Западу можемо да говоримо историјски о три облика клерикализма: привредном, политичком и културном (Mardešić, 2003).

Привредни се развио у периоду феудализма који је клирике учинио поседницима великих имања од којих су они добијали приходе. На Истоку су у овом периоду манастири, а не појединци, имали велике поседе али којима су, свакако, управљали клирици па је у обе варијанте клир био један одстубова феудалне привреде. Са нестанком феудалног поретка нестао је и овај облик средњовековног клерикализма.

Политички клерикализам одређујемо као велику световну моћ свештенства у предмодерним друштвима. Црква је у њима заузимала централно место формирајући светоназоре појединаца и пресудно утичући на све сфере како личног тако и државног живота. Давањем легитимитета и сакрализацијом друштвене моћи она је обезбеђивала себи политичност 
и конкретну световну моћ, било директно што је био чешћи случај на Западу, било индиректно, блискошћу, а у новијој историји чак и потпуном потчињеношћу носиоцима власти, што је био чешћи случај на Истоку. Овај облик је нестао или управо нестаје са нестанком традиционалних друштава, а раздвајањем Цркве и државе, демократизацијом друштва, а пре свега престанком потребе да политичка моћ има сакрални извор и легитимитет. На власт се у модерним друштвима долази вољом народа израженом на демократским изборима, а не милошћу Божијом.

Под културним клерикализмом подразумевамо културну и образовну надмоћ клира која је вековима била уобичајена појава свих друштава. Најобразованији, а у појединим периодима и једини писмени слој друштва су биликлирици. Овај облик клерикализма нестаје увођење општег и обавезног образовања. Знање постаје приступачно свима, а елитизам је строго лично, а не више сталешко достигнуће (Mardešić, 2003, стр. 129).

Како су у историји настајали, тако су са временом и развојем модерности сви ови друштвени облици клерикализма и нестајали да бисмо данас, тешко могли говорити о било каквој превласти клира у јавној сфери. Модерност је разградила све друштвене механизме који су у прошлости клиру обезбеђивали превласт у друштву и зато је апсолутно неутемељенстав о на пр. новој клерикализацији српског друштва који се понекад чује у јавности.

Закључујући тему о облицима друштвене клерикализације, погледајмо како је изгледао током друге половине 19. и прве 2о. века последњи покушај Римокатоличке цркве да се избори са модерношћу и сачува утицај клира на друштвени живот. Како Црква више није могла да се поистовети са светом који ју је окруживао и који је бивао све више секуларизован, а понекад и непријатељски расположен, сама Црква је покушала да формира идеално друштво (societasperfecta) које је унутар себе „удвостручавало“ свет. Како каже Altermatt могло се онда догодити да се неки католик:

... роди у католичкој болници, да од дечијег вртића до универзитета похађа католичке школе, да поред тога чита католичке часописе и новине, да касније изабира кандидате католичке странке и да у бројним католичким удружењима учествује као активан члан. Исто тако није било необично да се исти тај католик истовремено осигура у неком католичком социјалном уреду за случај несреће и болести и да свој новац чува у католичкој штедионици... Тиме је католичко под-друштво појединцу католику пружало нешто попут резервне домовине. (Greshake, 2010, стр. 210)

Друга половина 2о. века је распршила све наде да је тако нешто могуће али и пожељно. 
40 | Крстић, 3. Клерикализам и лаицизам - gве крајњостии у разумевању служби у Цркви-

\section{3. Клерикализам у Цркви}

Превласт свештеничког сталежа у религијском животу је уобичајена карактеристика свих религија - од анимистичких до сложених монотеистичких религија. Посреднички положај, улога посредника између „неба и земље“, ма у ком религијском кључу тумачили ове појмове, дају свештенству посебан положај унутар религијске заједнице. Овакве тенденције у Хришћанство улазе посредством теорије о посвећењу коју је, сматрамо, потребно подробније, и историјски и теолошки анализирати.

9. канон Неокесаријског сабора одржаног 315. године каже следеће:

Презвитер произведен (у чин) који је телом сагрешио пре тога и исповеди да је пре рукоположења сагрешио, нека не приноси (Литургији) остајући у чину због остале ревности. Јер кажу многи да рукоположење изглађује остале грехе ... (Свешиеиени канони Цркве, 2005, стр. 235)

Као што видимо, врло рано, већ почетком 4. века имамо наговештај паралеле између крштења и рукоположења - да и света тајна рукоположења мења природу рукоположеног и као и крштење спира пређашње грехе, сем телесних, тј. блуда, како овај канон тумачи Алексије Аристин у 12. веку (Свешйени канони Цркве, 2005, стр. 236). Последица оваквог теолошког става, што и чини суштину теорије посвећења, је да се сада само црквено тело раздваја на оне који су рукоположени тј. посвећени и на остале, непосвећене чланове Цркве.

На Западу је ово схватање кулминирало одлукама Тридентског сабора у 16. веку о немогућности рашчињења клирика. Као олакшавајућу околност треба да имамо на уму историјске околности, антиреформацијски дух овог сабора и покушај поновног успостављања пољуљаног ауторитета клира пред реформацијским лаицизмом. Овим се одлукама потпуно успоставља паралела између крштења и рукоположења - као што нико не може бити „раскрштен“ тако се и једном рукоположени више не може вратити у ред лаика.

Већ на први поглед је јасно да овакав став никада није, а засигурно никада и неће бити прихваћен у Православној Цркви. Свештени канони за веће преступе клирика и те како предвиђају рашчињење и повратак у службу лаика, и то без изузетка и увек истим редом - епископ, презвитер, ђакон. Из овога можемо да закључимо да, за разлику од Запада, на Истоку теорија о посвећењу никада није постала преовлађујуће, да не кажемо званично, теолошко учење. Она је остала у оквирима израза горепоменутог канона да „неки кажу“ али, са друге стране, то не значи да ово схватање није оставило озбиљне последице на црквени живот.

Прва последица је терминологија. Чланове Цркве који нису рукоположени најчешће називамо мирјанима тј. световњацима. Они би, дакле, били људи који припадају свету што у теолошкој терминологији 
подразумева одсуство Духа Светог. Светско је оно што је непосвећено, ван Цркве и што се противи Духу. Како су онда, запитаћемо се, крштени и миропомазани људи, хришћани - световњаци? На основу чињенице крштења овакав став је немогућ али на основу чињенице рукоположења сасвим могућ. Ако бисмо још даље желели да карикирамо ствари, могли бисмо рећи на основу терминологије да се на крштењу и миропомазању и не задобијају дарови Духа Светог као што се то дешава на рукоположењу. Овакво схватање се противи искуству Цркве али и непрекинутој вековној пракси крштавања било деце, било одраслих. Крштени је постао члан народа Божијег, лаик и задобио дарове Духа Светог, што ће рећи рукоположен је за обављање служঠе лаика у Телу Цркве.

Даље последице теорије посвећења које можемо назначити су различита дисциплина и учесталост причешћивањаисл. што генерално значи мању или већу пасивизацију лаика у области богослужења. Занимљива је још једна разлика између Западног и Источног искуства. На Истоку епископ или презвитер не може сам да служи евхаристију, она подразумева сабрање Народа Божијег, што на Западу није случај. Правно валидну литургију може сам самцит да служи канонски свештеник. Па ипак, и на Истоку лаици у Цркви постају само корисници сакралних добара које производе свештеници. Мора се признати да професионализација и подела занимања коју доноси модерност иде на руку оваквом виђењу односа клира и лаика. Клирици су експерти за свето. Лаик, сада у значењу неупућеног, незналице, непрофесионалца, уколико му је потребна нека услуга из области светог одлази и тражи помоћ професионалца, баш као и у свим другим областима.

Да се вратимо сада саморазумевању Цркве, односно како Она сама види сопствено добро функционисање. Црква представља заједницу служења. Она се састоји од оних који су се слободно определили да служе Господу и ближњима али не искључиво на основу својих знања и способности, иако се она не искључују, већ, превасходно, на основу воље Божије која се манифестује даровима Духа Светог. Дарови се дају на активност, за „сазидање Тела Христова“ (Еф 4, 12), а не за пасивност. У Цркви су пасивни само оглашени и покајници. Служба и дар се поистовећују те је тако немогуће раздвојити институционалну од харизматске структуре Цркве. А пошто је структура Цркве органска то подразумева различитост дарова: „И Он даде једне као апостоле, а друге као пророке, једне као јеванђелисте, а друге као пастире и учитеље за усавршавање светих у делу служења...” (Еф 4, 11-12). Целокупна структура Цркве ${ }^{2}$ се заснива и проистиче из структуре евхаристијске заједнице која је икона есхатона. Лаици, презвитери и ђакони сабрани око епископа, тј. све службе заједно сачињавају Народ Божији који служи свом Господу. Различитост служби не нарушава

2 Види Зизјулас, 2003, стр. 20-33. 
42 Крстић, 3. Клерикализам и лаицизам - gве крајњостии у разумевању служби у Цркви -

јединство Цркве (Афанасјев, 2001, стр. 17 и даље), напротив. Разликовање народа од предстојатеља такође не нарушава јединство Цркве. Ни једна од служби нису саме по себи Црква. Оне се не могу рангирати ни по значају, а поготову не по „количини“ благодети које претпостављају. Различите службе не стварају онтолошке разлике између њихових носилаца. Логика теорије посвећења да је превасходна последица рукоположења промена природе рукоположеног, а тек другостепена служење (Афанасјев, 2001, стр. 26), не одговара искуству Православне Цркве. Онтолошка разлика постоји само у односу крштени - некрштени, а не у оквирима Тела Христовог. У њему су сви свети и свештеници, односно служитељи Господу своме. Последице оваквог предањског става је да се служба лаика, за коју су они рукоположени крштењем, испољава у области свештенодејства где они саслужују својим предстојатељима.

\section{4. Лаицизам у Цркви}

И поред мање или веће пасивизације лаика током историје, свест о потреби њиховог активног учешћа у животу Цркве никада није нестала из свести Цркве. Тако је пасивизација у једној области наметнула активирање лаика у другој области, а то је црквена управа. Већина каноничара традиционалног усмерења сматра да је то област у којој ангажовање лаика треба да буде максимално. Људска логика, а свакако и дух времена и тенденције демократизације друштва које утичу на Цркву, су овде доследне и јасне. Сакрално је за непосвећене недоступно, а профаним не треба да се баве посвећени. Сваком своје - посвећенима сакрално, световњацима профано. Овом логиком су се водила и многа новија црквена законодавства помесних Православних Цркава и широм отворила врата управе лаицимаи то не само да учествују у управи, што је свакако добро и пожељно, већ и да сами управљају. Устав СПЦ из 1931. године који је још на снази, на нивоу парохије подразумева два ентитета - парохију као богослужбену заједницуна чијем је челу парох и црквену општину као административну заједницу на чијем је челу лаик, директно долазећи тако уконтрадикцију са канонским предањем које не познаје овај дуализам и који у пракси зна да изазове оштре сукобе. Овакав лаицизам који личи на протестантско разумевање Цркве је реакција на претерани клерикализам који обично приписујемо Римокатоличкој цркви. Питамо се има ли ту места за Православље или смо ми православни осуђени да лавирамо између ова два пола заступајући час једно, а час друго становиште?

Решење проблема се не може наћи у људској логици. Људска логика каже да и у Цркви као и у свим другим колективима, постоје различити интереси. Службе управо изражавају те различите сталешке интересе за које свако треба да се бори, по могућству цивилизовано у демократској 
процедури. Та се логика манифестовала у многим свештеничким или лаичким удружењима током 20. века.

Решење проблема се налази у поновном откривању воље Божије. Ми у Цркву нисмо ушли да бисмо спроводили своју вољу или задовољавали сопствене интересе. У Цркви може да постоји само „интерес“ Божији којем смо ми активни сарадници и не смеју да постоје супротстављени сталешки интереси. Свако у Цркви дела на основу и у оквиру своје службе јер је то воља Божија и баш за ту појединачну службу је сваки од нас добио дарове Духа Светога као дар а не на основу сопствених заслуга. Проблем да лаици управљају Црквом или лаицизација црквеног живота се састоји у томе што лаици не поседују дарове Духа Светог за управљање Црквом. Служठа управе тј. пастирска служба је део епископске службе зашта он рукоположењем задобија дарове, а зашта, опет, лаици немају дарове. Следовање вољи Божијој израженој кроз различите службе представља услов доброг функционисања Тела Христовог.

Као закључак, могу да кажем да ако као верујући људи који исповедају веру у Цркву, заиста желимо Њен напредак, онда се наш први и одлучујући корак састоји у поновном откривању значења, а пре свега садржаја појединих служби да бисмо могли у пракси да избегнемо обе крајности у њиховом разумевању како клерикализам тако и лаицизам.

\section{Литература:}

- Афанасјев, Н. (2001). Служење мирјана (лаика) у Цркви. Вршац.

- Altermatt, U. (1975). Abschied vom katholischen Blockdenken. Civitas, 30, 564, преузето од: Greshake, G. (2010). Biti svećenik u ovom vremenu. Zagreb: KS.

- Зизјулас, J. (2003). Православље. Београд.

- Mardešić, Ž. (2003). O klerikalizmu i protuklerikalizmu danas. Nova Prisutnost, 1(1), 127-131.

- Свешиенен канони Цркве. (2005). Београд. 


\title{
Zoran Krstić
}

University of Belgrade, Faculty of Orthodox Theology, Belgrade

\section{Clericalism and Laicism - Two Extremes in the Understanding of the Church Service}

\begin{abstract}
$A$ uthor in this paper discusses the exaggeration in understanding the conA tent of church services that have historically often manifested as clericalism, as one sex, and laicism as its opposite. Starting from the clericalism one should point to different forms of which it had been winning throughout history, such as political, social and cultural clericalism. The emphasis in this analysis is that the author considers clericalism in the Church community by seeing its origins and causes of the so-called theory of sanctification, which is manifested in different ways in the Church life of the Western and Eastern Churches. The first consequence of this theory is the change of the term layman in terms of the member of God's people, by the layman in terms of the world. The second consequence is a lesser or greater passivity of the laity in Church life. He sees the resolution of issues in a revival of the traditional ecclesiology that identifies the service and the gifts of the Holy Spirit, and thus does no separate institutional structure of the charismatic Church. The last part deals with the consequences of laicism in the Church life as a reaction to the excessive clericalism.
\end{abstract}

Key words: Service, clericalism, laicism, layman, the will of God, the structure of the Church.

Датум пријема чланка: 9. 12. 2012.

Датум прихватања чланка за објављивање: 12. 12. 2012. 